$339.9: 327.82(477)$

\title{
IMPERATIVES OF INTERNATIONAL COOPERATION FOR ECONOMIC DIPLOMACY OF UKRAINE
}

\section{ІМПЕРАТИВИ МІЖНАРОДНОЇ КООПЕРАЦІЇ ДЛЯ ЕКОНОМІЧНОЇ ДИПЛОМАТІї УКРАЇНИ}

\section{ИМПЕРАТИВЫ МЕЖДУНАРОДНОЙ КООПЕРАЦИИ ДЛЯ ЭКОНОМИЧЕСКОЙ ДИПЛОМАТИИ УКРАИНЫ}

\author{
Flissak K. A.
}

$\mathrm{PhD}$ (Economics), Associate professor, doctoral student in Department of International business, Taras Shevchenko Kyiv National University, Ukraine. E-mail: Flissak.K@ukr.net

\section{Фліссак К. А.}

Кандидат економічних наук, доцент, докторант кафедри міжнародного бізнесу Інституту міжнародних відносин Київського національного університету імені Тараса Шевченка. E-mail: Flissak.K@ukr.net

Флиссак К. А.

Кандидат экономических наук, доцент, докторант кафедры международного бизнеса, Киевский национальный университет им. Тараса Шевченко. E-mail: Flissak.K@ukr.net

Abstract. Increased competition in global markets forces producers from different countries to resort to new forms of collaboration with their foreign partners. One of these forms which are increasingly used by actors in international business is the international cooperation as a special type of economic partnership. Its use allowed Germany to take the leading position in the world economy, and therefore this experience is essential for further study.

An equally important aspect of modern international economic activity is the support of business entities by relevant state institutions in world markets. As a rule, most of such tools of the state support are related to the economic diplomacy which in the XXI century become an important factor in the success of the country and its business representatives abroad.

This article studies certain aspects of the economic diplomacy of Ukraine and defines its interconnection with the use of the practice of international cooperation in the context of their impact on the results of foreign economic activity of Ukraine. It allowed to lead and motivate several proposals on improving the effectiveness of the economic diplomacy of Ukraine.

Key words: foreign economic activities, export, import, efficiency, international cooperation, economic diplomacy.

Анотація. Загострення конкуренщії на світових ринках змушує товаровиробників різних краӥн вдаватись до пошуку нових форм взаємодії з своӥми зарубіжними партнерами. Однією з таких форм, які все частіше застосовуються суб'єктами міжнародного бізнесу, $\epsilon$ міжнародна кооперація як особливий різновид економічного партнерства. Саме її використання свого часу дозволило ФРН вийти на провідні позиції в світовій економічі, а тому даний досвід має важливе значення для подальшого дослідження.

Не менш важливим аспектом сучасної міжнародної економічної діяльності стала підтримка суб'єктів бізнесу з боку профільних установ держави на світових ринках. Як правило, більшість інструментів такого державного супроводу належать до економіч- 
ної дипломатії, яка в ХХІ ст. стала важливим чинником успіху країни та ї̈ представників за кордоном.

В даній статті наведено дослідження окремих аспектів економічної дипломатії Украӥни, а також визначено ї̈ взаємозв'язок з використанням практики міжнародного кооперування в контексті впливу на результати зовнішньоекономічної діяльності України. Це дозволило навести та обтрунтувати ряд пропозищї щуодо підвищення результативності економічної дипломатії намої країни.

Ключові слова: зовнішньоекономічна діяльність, експорт, імпорт, ефективність, міжнародна кооперація, економічна дипломатія.

Аннотация. Обострение конкуренции на мировых рынках заставляет товаропроизводителей разных стран прибегать к поиску новых форм взаимодействия со своими зарубежными партнерами. Одной из таких форм, которые все чаще применяются субъектами международного бизнеса, является международная кооперачия как особая разновидность экономического партнерства. Именно её использование в свое время позволило ФРГ выйти на ведущие позищии в мировой экономике, а потому данный опыт имеет важное значение для дальнейшего исследования.

Не менее важным аспектом современной международной экономической деятельности стала поддержка субъектов бизнеса со стороны профильных учреждений государства на мировых рынках. Как правило, большинство инструментов такого государственного сопровождения относятся к экономической дипломатии, которая в XXI веке стала важным фактором успеха страны и ее представителей за рубежом.

В данной статье приведены исследования отдельных аспектов экономической дипломатии Украины, а также определена её взаимосвязь с использованием практики международного кооперирования в контексте влияния на результаты внешнеэкономической деятельности Украинь. Это позволило привести и обосновать ряд предложения по повылению результативности экономической дипломатии Украины.

Ключевые слова: внешнеэкономическая деятельность, экспорт, импорт, эффективность, международная кооперация, экономическая дипломатия.

The current problem. The foreign economic activity of enterprises and business structures of Ukraine are intended to be an active part of the socio-economic development of the country and raising of its international prestige. At that, integration of Ukrainian economy into the world economy involves active participation in the modern international division of labour and technical exchange, global trade and multi-faceted cooperation with all countries and international partners on a mutually beneficial basis. The key question here remains the problem of promoting and defending of national economic interests. These goals can be achieved by a number of factors which have managerial, organizational, operational, legal and financial nature. An important role here can play new unconventional forms and methods of organization and support of foreign economic activities, including through the full use of the mechanisms of economic diplomacy. Considerable untapped potential in this area for Ukraine contained in international cooperation.

Brief literature review Various aspects of foreign economic activities in the field of trade and investment partnership of countries, their participation in integration processes with the use of a range of forms and methods of cooperation were considered in works of such scientists as O. Bilorus, V. Budkin, I. Burakovsky, A. Filippenko, I. Gladij, T. Gordeeva, V. Heyets, T. Kalchenko, A. Kredisov, V. Leontiev, D. Lukyanenko, Y. Makogon, A. Mazaraki, V. Novitsky, Y. Pakhomov, J. Sachs, S. Sokolenko, J. Stiglitz, T. Tsygankova, I. Shkola and others. Question of use of diplomatic support instruments in the promotion abroad of the economic interests of 
the country are researched by N. Bayne, G. Саггоп de la Carriere, D. Degterev, A. Likhachev, E. Molendowski, W. Polan, V. Schetinin, O. Sharov, V. Vergun, S. Woolkock, Yu. Zhou.

The purpose of this article. However, virtually out of the spotlight of the Ukrainian scientists remains such a segment of the foreign economic activity development as participation in the international cooperation, the role of which increases significantly in conditions of escalating competition in a globalized world. The partition of spheres of influence and fulfil of their own economic interests of players in international markets can occur either through mergers and acquisitions, or through cooperation. In the latter case achieves the effect of turning a competitor into a partner. In these processes the economic diplomacy can and should play an important role.

The important research results. Indicators of foreign economic activity of Ukraine during last years show the gradual formation of the new dynamics of export-import operations, as well as the emergence of certain problems related to retention of positions in foreign markets. As the gross domestic product of Ukraine significantly depends on the volume of exports of goods and services, the efficiency of foreign trade do not lose their relevance. Moreover, the impact of crisis factors on the participants of international markets, increased competition, despite Ukraine's membership in the WTO, new agreements for free trade areas enhance the need for increased activity of national agents with foreign partners.

The current value of the foreign economic relations is reveal in the fact that they allow to balance the economic and social development of both the country and individual enterprises and business entities. Hereby it is very important to balance exports and imports of goods. However, it should be keep in view that even balanced exports and imports may not always indicate the effectiveness of foreign trade operations, at least for one of the parties. Balance of exports and imports by the currency between partner countries does not exclude that one of them will be of great benefit, and another - less. Therefore, a special role here must be played by the economic diplomacy tools, which enable and support cooperation between countries and their economic entities on the basis of mutual interest and the maximum accounting of interests of the sides.

Ukraine's interests in relation to the partner countries in foreign trade primarily are characterized by a geographical structure of exports and imports. Data regarding its dynamics over the last 20 years are shown in table 1.

Table 1

Aggregated geographical structure of foreign trade in goods of Ukraine, in \% [10]

\begin{tabular}{|l|r|r|r|}
\hline & $\mathbf{1 9 9 5}$ & $\mathbf{2 0 0 5}$ & $\mathbf{2 0 1 4}$ \\
\hline Export by region of destination & 100 & 100 & 100 \\
\hline Developed economies - total & 25.4 & 35.6 & 34.8 \\
\hline including: & & & \\
\hline Europe - total & 21.8 & 31.4 & 31.9 \\
\hline including European Union & 21.0 & 30.1 & 31.5 \\
\hline USA & 2.6 & 2.8 & 1.2 \\
\hline Japan & 0.6 & 0.2 & 0.4 \\
\hline other & 0.5 & 1.2 & 1.3 \\
\hline Transition economies & 51.5 & 32.4 & 28.9 \\
\hline Developing economies - total & 20.3 & 32.0 & 36.2 \\
\hline including: & & & \\
\hline Africa & 1.4 & 7.0 & 9.5 \\
\hline America & 1.4 & 2.3 & 1.2 \\
\hline Eastern, Southern and South-Eastern Asia & 11.6 & 11.3 & 13.3 \\
\hline Western Asia & 5.9 & 11.4 & 12.2 \\
\hline
\end{tabular}


The data of table 1 indicate export potential of Ukraine on the markets of the EU and CIS countries (according to UNCTAD classification the last ones belong to "the countries with the transition economy"). In connection with the signing of the Association Agreement between Ukraine and the European Union, this trend will continue to develop. The table 2 reflects the performance of external trade in goods of Ukraine in general and in particular with the European Union. The dynamics of Ukrainian merchandise export showed growth from 2000 to 2013, but in $2014-2015$ due to certain reasons, there was a significant reduction both in general and with the European Union. The ratio of coverage import by export in trade between Ukraine and the EU since 2005 is below one. To complete the analysis of trade relations Ukraine with the EU is necessary to make assessment of the situation from the position of the European Union.

As shows the analysis, the trade-economic relations between the EU and Ukraine, which should serve as the basis for realization of country's aspirations of European integration, are characterized by a relatively low level of development. According to EU statistics, the share of Ukraine in total import of the EU from third countries (so called "Extra-EU") in 2005 - 2015 ranged in diapason $0,7 \%-0,8 \%$, only in 2007 and in 2011 it reached $0.9 \%$ and in $2015-0.7 \%$. Hereby the volume of imports in 2015 was decreased by $7 \%$ relatively from previous year. The share of EU exports to Ukraine in general volumes to third countries (Extra-EU) is gradually reduced from $1.9 \%$ in 2008 to $1.4 \%$ during $2011-2013,1 \%$ in 2014 and $0.8 \%$ in 2015 . The volume of European exports to Ukraine in 2014 decreased to the level of the previous year by $28.9 \%$, and in 2015 - by $18 \%$. Foreign trade balance EU trade with Ukraine is positive and its value is ranged from 10515 million Euros in 2008 to 9222 million Euros in 2012, 3262 million Euros in 2014 and 1154 million Euros in 2015 [4].

As evidenced by domestic statistics, Ukraine had a negative balance of foreign trade with EU countries in goods trade during $2004-2015$ (table. 2). Hereby its value as a percentage of imports ranged from $15.7 \%$ in 2005 to $38 \%$ in $2013,19.2 \%$ in 2014 and $15.1 \%$ in 2015 . However, the decrease in the relative value of the negative balance in the last 2 years was not due to the increase of exports, but due to more rapid decline of imports relatively to decline exports to the EU.

Table 2

The efficiency characteristics of external trade of Ukraine with the European Union*

\begin{tabular}{|c|c|c|c|c|c|c|c|c|c|c|}
\hline & \multirow{3}{*}{ Year } & \multirow{3}{*}{$\begin{array}{c}\text { Direc- } \\
\text { tion }\end{array}$} & \multicolumn{2}{|c|}{ Export } & \multicolumn{2}{|c|}{ Import } & \multirow{2}{*}{\multicolumn{2}{|c|}{$\begin{array}{c}\text { The foreign trade } \\
\text { balance }\end{array}$}} & \multirow{3}{*}{$\begin{array}{c}\text { The cov- } \\
\text { erage } \\
\text { ratio of } \\
\text { imports } \\
\text { by exports }\end{array}$} & \multirow{3}{*}{$\begin{array}{c}\text { The } \\
\text { amount } \\
\text { of im- } \\
\text { ports by } \\
\$ 1 \text { of } \\
\text { exports }\end{array}$} \\
\hline & & & \multirow{2}{*}{$\begin{array}{c}\$ \\
\text { Million }\end{array}$} & \multirow{2}{*}{$\begin{array}{c}+,- \text { in } \% \\
\text { compa-red } \\
\text { to the pre- } \\
\text { vious } \\
\text { period }\end{array}$} & \multirow{2}{*}{$\begin{array}{c}\text { \$ } \\
\text { Million }\end{array}$} & \multirow{2}{*}{\begin{tabular}{|c|}
,+- in $\%$ \\
compa-red \\
to the pre- \\
vious \\
period
\end{tabular}} & & & & \\
\hline & & & & & & & $\begin{array}{c}\$ \\
\text { Million }\end{array}$ & $\begin{array}{l}\text { in } \% \text { to } \\
\text { imports }\end{array}$ & & \\
\hline \multirow[t]{2}{*}{1.} & 2000 & Total & 14572,5 & 25.8 & 13956,0 & 17.8 & 616.5 & 4.4 & 1.044 & 0.96 \\
\hline & & EU & 4576,3 & 24.9 & 4047,7 & 17.0 & 528.6 & 13.1 & 1.131 & 0.88 \\
\hline \multirow[t]{2}{*}{2.} & 2005 & Total & 34228,4 & 134.9 & 36136,3 & 158.9 & - 1907,9 & 5.3 & 0.947 & 1.06 \\
\hline & & EU & 10293,3 & 124.9 & 12211,3 & 201.7 & - 1918,0 & 15.7 & 0.843 & 1.19 \\
\hline \multirow[t]{2}{*}{3.} & 2010 & Total & 51405,2 & 50.2 & 60742,2 & 68.1 & $-9337,0$ & 15.4 & 0.846 & 1.18 \\
\hline & & $\overline{E U}$ & 13085,3 & 27.1 & 19151,4 & 56.8 & $-6066,1$ & 31.7 & 0.683 & 1.46 \\
\hline \multirow[t]{2}{*}{4.} & 2013 & Total & 63320,7 & 23.2 & 76986,8 & 26.7 & - 13666,1 & 17.8 & 0.822 & 1.22 \\
\hline & & EU & 16758.6 & 28.1 & 27046,5 & 41.2 & - 10287,9 & 38.0 & 0.619 & 1.01 \\
\hline \multirow[t]{2}{*}{5.} & 2014 & Total & 53901,7 & -14.9 & 54428,7 & -29.3 & -527.0 & 0.9 & 0.99 & 1.01 \\
\hline & & $\mathrm{EU}$ & 17002,9 & 2.6 & 21069,1 & -22.1 & $-4066,2$ & 19.2 & 0.807 & 1.24 \\
\hline \multirow[t]{2}{*}{6.} & 2015 & Total & 38127,1 & -29.3 & 37516,4 & -31.1 & 610.7 & 1.6 & 1.016 & 0.98 \\
\hline & & $\mathrm{EU}$ & 13015,2 & -23.5 & 15330,2 & -27.2 & $-2315,0$ & 15.1 & 0.849 & 1.18 \\
\hline
\end{tabular}

* Calculated by the author based on the data: [8]. 
Overall, positive dynamics of investment cooperation between Ukraine and the EU over the period since 2003 has stalled in 2014-2015. If at the end of 2003 in Ukraine has been invested by the European Union 3805,3 million U.S. dollars direct investment, that at the end of $2010-$ 35225.2 million and at the end of 2013 - 44423,0 million, however, for 2014, the amount decreased by 8.8 billion, and for 2015 another 2.6 billion U.S. dollars. Thus, the direct investments of the EU into the Ukrainian economy in 2014 - 2015 declined compared to their peak in 2013 on $25.6 \%$ [3].

The given actual data shows the weaknesses and focuses on core national interests of Ukraine in trade and economic cooperation with the EU. Particularly they are, at first, the need for a balanced foreign trade and reduce the negative balance, and at second, the need to restore the positive dynamics in attracting to the national economy of direct investment from the EU, including integration into European resource potential in the context of the implementation of the "Investment plan for Europe".

Significant opportunities in ensuring of national economic interests in foreign trade and investment cooperation of Ukraine with European partners can receive a positive decision as a result of effective implementation of the Association Agreement between Ukraine and the European Union (in Ukraine it ratified by Law №1678-VII dated 16.09.2014) [1]. As a guide to action and the imperatives of the European Union in activities of authorized institutions and actors of economic diplomacy of Ukraine should be the basic positions and regulations of the Agreement related to the economic cooperation. It is primarily the Title IV "Trade and trade-related matters", Title V "Economic and sector cooperation", Title VI "Financial cooperation, with anti-fraud provisions" Title VII "Institutional, general and final provisions".

The commodity structure of exports also must be taken into account in the development of complex of measures on overcoming of problematic situations in merchandise exports and providing the retention of positions in already developed foreign markets and identify opportunities for expansion. Table 3 summarizes data describing the specified structure.

Table 3

Aggregated structure of foreign trade in goods of Ukraine by product, in \% $[10: 117,131]$

\begin{tabular}{|l|r|r|r|r|r|r|}
\hline \multirow{2}{*}{ Product group (by main SITC Revision 3) } & \multicolumn{3}{|c|}{ Export } & \multicolumn{3}{|c|}{ Import } \\
\cline { 2 - 7 } & $\mathbf{1 9 9 5}$ & $\mathbf{2 0 0 5}$ & $\mathbf{2 0 1 4}$ & $\mathbf{1 9 9 5}$ & $\mathbf{2 0 0 5}$ & $\mathbf{2 0 1 4}$ \\
\hline Total & 100 & \multicolumn{1}{|c|}{100} & \multicolumn{1}{|c|}{100} & \multicolumn{1}{|c|}{100} & \multicolumn{1}{c|}{100} & 100 \\
\hline include: & & & & & & \\
\hline All food items & 19.0 & 12.4 & 30.7 & 7.9 & 7.2 & 10.8 \\
\hline Agricultural raw materials & 1.0 & 1.5 & 1.8 & 2.4 & 1.3 & 1.1 \\
\hline Fuels & 4.3 & 9.8 & 3.7 & 47.8 & 29.8 & 27.8 \\
\hline $\begin{array}{l}\text { Ores, metals, precious stones } \\
\text { and non-monetary gold }\end{array}$ & 8.2 & 7.2 & 9.9 & 3.1 & 4.3 & 3.1 \\
\hline Manufactured goods & 66.4 & 68.4 & 53.6 & 37.9 & 57 & 56.6 \\
\hline include: & & & & & & \\
\hline Chemical products & 12.8 & 9.1 & 5.2 & 6.7 & 11.8 & 16.7 \\
\hline Machinery and transport equipment & 14.1 & 13.1 & 13.2 & 17.0 & 26.4 & 20.8 \\
\hline other manufactured goods & 39.4 & 46.3 & 35.2 & 14.2 & 18.7 & 19.1 \\
\hline
\end{tabular}

As can see from table 3, over the last 20 years in the Ukrainian exports has significantly increased the proportion of food products (from $19.0 \%$ to $30.7 \%$ ) with a simultaneous decrease in the share of industrial goods (from $66.4 \%$ to $53.6 \%$ ). 
According to UNCTAD data, characteristic for Ukraine's foreign trade is that the main product groups in its exports are raw materials, or semimanufactures products made from ferrous metals (table 4).

Export structure of Ukraine by product [10:168]

\begin{tabular}{|c|l|c|c|}
\hline \multicolumn{2}{|c|}{$\begin{array}{c}\text { Leading products exported based } \\
\text { on SITC Revision 3 (3-digit level) }\end{array}$} & \multicolumn{2}{c|}{$\begin{array}{c}\text { Average value in percent } \\
\text { (2013-2014) }\end{array}$} \\
\hline \multirow{2}{*}{ Code } & \multicolumn{1}{|c|}{ Label of product group } & $\begin{array}{c}\text { of merchandise } \\
\text { export of } \\
\text { Ukraine }\end{array}$ & $\begin{array}{c}\text { of the volume of } \\
\text { world exports by } \\
\text { commodity group }\end{array}$ \\
\hline & All commodity groups & 100 & 0.31 \\
\hline 672 & Ingots, Iron steel primary products & 8.3 & 13.99 \\
\hline 44 & Maize unmilled, excl. sweet corn & 6.1 & 10.39 \\
\hline 421 & Fixed veg fats, oils, "soft" & 6.1 & 9.47 \\
\hline 281 & Iron ore and concentrates & 6 & 2.74 \\
\hline 673 & Flat iron non-alloy steel products & 5.4 & 4.23 \\
\hline 676 & Iron \& steel bars, rods, sections & 5.3 & 3.56 \\
\hline 41 & Wheat incl. spelt, meslin, unmilled & 3.6 & 4.29 \\
\hline 671 & Pig \& sponge iron, ferro alloys etc & 3.2 & 5.20 \\
\hline 222 & Oil seeds, oleaginous for soft oil & 3.1 & 2.25 \\
\hline 791 & Railway vehicles and equipment & 2.8 & 5.40 \\
\hline & Total by given positions & 49.9 & \\
\hline & Remainder & 50.1 & \\
\hline
\end{tabular}

As $49.9 \%$ of Ukrainian exports fall to the share of 10 given leading commodity positions $(2013-2014)$, it is advisable to pay attention to the ratio between price changes and the dynamics of the physical volume of exports by these commodity groups. Table 5 shows the indices of average export prices and indices of physical volumes of commodity positions, which are allocated to the statistics of UNCTAD (table 4) as the main commodity groups of Ukrainian exports.

Opportunely it should note that such analytical comparisons, particularly in the modern economic diplomacy of Ukraine, with some exceptions [Flissak A. A., 2005], are almost non-existent.

Table 5

Indices of average export prices and physical volumes of Ukrainian export on separate merchandise groups, in \% (calculation based on [7:80-85])

\begin{tabular}{|c|l|c|c|c|c|}
\hline \multirow{2}{*}{ Code } & \multicolumn{2}{|c|}{$\mathbf{2 0 1 4}$} & \multicolumn{2}{c|}{$\mathbf{2 0 1 5}$} \\
\cline { 1 - 5 } $\begin{array}{c}\text { (by Ukrainian } \\
\text { Classifi-cation } \\
\text { of Commodi- } \\
\text { ties) }\end{array}$ & \multicolumn{1}{|c|}{$\begin{array}{c}\text { The } \\
\text { index of } \\
\text { average } \\
\text { prices }\end{array}$} & $\begin{array}{c}\text { The } \\
\text { index of } \\
\text { physical } \\
\text { volume }\end{array}$ & $\begin{array}{c}\text { The } \\
\text { index of } \\
\text { average } \\
\text { prices }\end{array}$ & $\begin{array}{c}\text { The } \\
\text { index of } \\
\text { physical } \\
\text { volume }\end{array}$ \\
\hline 10 & Cereals & 89.5 & 127.2 & 78.9 & 117.3 \\
\hline 11 & Flour-grinding products & 90.0 & 102.9 & 80.1 & 118.3 \\
\hline 12 & Oil seeds and fruits & 92.7 & 91.5 & 83.4 & 104.9 \\
\hline 15 & Animal or plant fats and oils & 80.2 & 143.0 & 93.8 & 92.1 \\
\hline 26 & Ores, slags, ashes & 86.4 & 110.8 & 59.8 & 106.7 \\
\hline 72 & Ferrous metals & 97.1 & 92.9 & 75.0 & 83.5 \\
\hline 73 & Preparations from ferrous metals & 89.9 & 76.3 & 84.4 & 64.3 \\
\hline 86 & Rail locomotives & 90.3 & 36.9 & 80.4 & 31.2 \\
\hline
\end{tabular}


Draws attention to a significant difference in the indices of average export prices and volumes by next merchandise groups: 2014 - cereals with $89.5 \%$ and $127.2 \%$ accordingly, flourgrinding products with $90,0 \%$ and $102,9 \%$, animal or plant fats and oils with $80.2 \%$ and $143,0 \%$, the ores, slags, ashes $86,4 \% 110,8 \%$; in 2015 - cereal with $78.9 \% 117,3 \%$, flour-grinding products with $80,1 \% 118,3 \%$, animal or plant fats and oils with $83.4 \% 104,9 \%$, the ores, slags, ashes $59,8 \%$ and $106.7 \%$.

The index shows how change both average export prices for the goods and volumes of their shipment to the buyers (importers). Significant difference in indices of the physical volume indicates that export prices are reduced, and the physical volumes (physical indicators of export) of products grow, that means that was sold more products at lower prices. The result is the shift the accumulation of financial result from exporter to importer, and in the end, the Ukrainian economy receive losses.

Real and effective direction of change of the situation can be considered the use by Ukraine the advantages of international division of labor, which leads to the deepening in specialization and concentration of production both in larger enterprises and in individual countries. This allows to use the latest equipment and technology, to reduce the cost of production per unit of output and to increase productivity. Referring to the necessity of intensification of activity of Ukrainian business and the relevant government and diplomatic entities in relation to establishing the participation of the Ukrainian side in international cooperation, primarily with EU countries.

It should be take into account the next fact. At the conclusion of agreements on specialization and cooperation with the aim of production concentration, can be developed two ways of partnership. The first one is orientation of partners on simple transactions on exchange of commodities, efficiency from the cooperation of which will be fairly minor, and the partnership will be short-lived or temporary. The second is the creation of modern systems of production and distribution of products, with specification of shares, obligations and benefits of each of the members of the cooperation.

Currently, the Germany is the most effective user of advantages from international cooperation and successful implementation of this model provides up to $48 \%$ of export via a cooperative supplies that are based on long-term joint activities [2].

When determining tasks and directions of activity of the institutions of economic diplomacy on the organization of participation of Ukrainian business in international cooperation it is important to consider proven in Germany components of the modern cooperative model of the German economy:

- the first, the allocation determining factors for cooperation;

- the second, the definition of the scope of cooperation;

- the third, the grouping and analysis of the possible positive economic effects for future cooperative activities;

- the fourth, the systematization of the possible risks that may be hiding by cooperating activity of partners [Flissak K. A., 2009: 57].

In the exports activity, the use of the cooperative model offers significant benefits, among which are the following ones: the ability to offer the most favorable prices for buyers and consumers; the offer of additional products, goods and services; the opening and the conquest of new external markets; win in attracting of new consumers and customers; undertaking the realization of the complete and complex customer orders; retrenchment on advertising, sales activities and logistics [9]. 
We consider that the imperatives for economic diplomacy of Ukraine in the implementation of the participation of national business entities in the international cooperation, primarily in the markets of the European Union, are:

- define the goals of cooperation;

- the choice of partners in international cooperation;

- the choice of sectors and areas of activities;

- definition of tools of decision-making;

- the choice of forms of cooperation;

- consideration of influence of different factors, such as risks, benefits, attractiveness, stimulation, state support, creation of framework conditions etc.;

- the use of mechanisms of state assistance and support;

- establishment of a coordination center of cooperation [Flissak K. A., 2009: 188].

Conclusions. With the purpose of defending national economic interests of Ukraine in foreign markets, overcome the negative trends in merchandise exports, hold positions in already developed foreign markets, identify opportunities for export expansion in new directions, concentrate main national interests of Ukraine towards the EU there are advisable:

- first, to develop a set of measures for the achievement of a more balanced foreign trade with reducing its negative balance;

- secondly, to introduce in practice activity of institutions of economic diplomacy permanent monitoring of indices of average export prices and index of physical volumes of Ukrainian merchandise exports to prevent displacement accumulation of a financial result from Ukrainian exporters to foreign importers, and financial losses of the Ukrainian economy;

- thirdly, attract the attention of Ukrainian scientists and practitioners in the sphere of foreign economic activities and institutions of economic diplomacy at expand and intensify participation of Ukraine in international cooperation, taking into account the European experience and existing requirements for build of effective models.

\section{References}

1. Association Agreement between the European Union and the European Atomic Energy Community and their member states, of the one part, and Ukraine, of the other part (ratified by Law № 1678-VII from 16. 09. 2014) - http://zakon4.rada.gov.ua/laws/show/984_011

2. Außenhandel. Zusammenfassende Übersichten für den Außenhandel. Fachserie 7 Reihe 1. August 2015. Statistische Bundesamt; Wiesbaden. - 2015. - 97 s.

3. Direct foreign investment from EU countries in Ukraine. - Available at: $<$ www.ukrstat.gov.ua $>$

4. European Union, Trade in goods with Ukraine. European Commission. Directorate-General for Trade. 14. 04. 2016 (10 P.) - Available at: <http://trade.ec.europa.eu/doclib/docs/2006/ september/tradoc_113459.pdf $>$

5. Flissak A. A. (2005). - Zovnishnyoekonomichni predstavnytztva krajiny za kordonom: mizhnarodnyj dosvid ta ukrajinski perspektyvy reformuvannya' [Foreign economic representatives offices of the country: international experience and Ukrainian perspectives of reform], Economic Annals-XXI 11-12: 8-13.

6. Flissak K. A. (2009). - Formuvannya kooperatzijnoji modeli rozvytku bilateralnyh economichnyh vidnosyn Ukrajiny I Nimechchyny' [Formation of cooperation model of development of bilateral economic relations between Ukraine and Germany]: Monografia. Ternopil: Novyj Kolir: 288. 
7. Foreign trade of Ukraine with goods and services in 2015. Statistical yearbook (2016) [Zovnishnya torgivlya Ukrajiny tovaramy ta poslugamy u 2015 rotzi. Statystuchnyj zbirnyk]: 159.

8. Geographic structure of exports and imports of goods. - Available at: <www.ukrstat.gov.ua>

9. GründerZeiten Nr. 11, aktualisierte Ausgabe 03/2006. Bundesministerium für Wirtschaft und Technologie. $-4 \mathrm{~s}$.

10. UNCTAD. Handbook of Statistics 2015. - United Nations, New York, 2015. 376 p.

\section{Список використаних джерел}

1. Угода про Асоціацію між Україною, з однієї сторони, та Європейським Союзом, Європейським співтовариством $з$ атомної енергії і їхніми державами-членами, з іншої сторони (Угоду ратифіковано із заявою Законом № 1678-VII від 16.09.2014). - [Електронний ресурс] - Режим доступу: http://zakon4.rada.gov.ua/laws/show/984_011.

2. Außenhandel. Zusammenfassende Übersichten für den Außenhandel. Fachserie 7 Reihe 1. August 2015. Statistische Bundesamt; Wiesbaden; 2015, 97 s.

3. Прямі іноземні інвестиції з країн $С$ в в економіці України. - [Електронний ресурс] Режим доступу: www.ukrstat.gov.ua.

4. European Union, Trade in goods with Ukraine. European Commission. Directorate-General for Trade. 14. 04. 2016. - 10 p. - [Електронний ресурс] - Режим доступу: http://trade.ec. europa.eu/doclib/docs/2006/september/tradoc_113459.pdf.

5. Фліссак А. А. Зовнішньоекономічні представництва країни за кордоном: міжнародний досвід та українські перспективи реформування / А. Фліссак // Економічний часопис - XXI. - 2005. - № 11-12. - C. 8-13

6. Фліссак К. А. Формування коопераційної моделі розвитку білатеральних економічних відносин України і Німеччини: Монографія. / К. Фліссак - Тернопіль: Новий колір. - 2009. - 288 с.

7. Зовнішня торгівля України товарами та послугами у 2015 році. Статистичний збірник. - К. : Держстат України, 2016. - 159 с.

8. Geographic structure of exports and imports of goods. - [Електронний ресурс] - Режим доступу: www.ukrstat.gov.ua.

9. GründerZeiten Nr. 11, aktualisierte Ausgabe 03/2006. Bundesministerium für Wirtschaft und Technologie, S.1.

10. UNCTAD. Handbook of Statistics 2015. - United Nations, New York, 2015. - 376 p. 